\title{
Properties of Arsenic Sulfide Glass
}

\section{Francis W. Glaze, Douglas H. Blackburn, Jerome S. Osmalov, ${ }^{2}$ Donald Hubbard, and Mason H. Black ${ }^{3}$}

\begin{abstract}
Samples of arsenic sulfide glass were investigated to determine their chemical and physical properties. Among the properties reported are the hygroscopicity, chemical durability, hydrogen electrode function, expansivity, elastic moduli, modulus of rupture, hardness, transmittance, and indices of refraction.

The main interest in arsenic sulfide glass, for the present, is for its transmittance in the infrared. It is transparent to infrared energy out to approximately 13 microns. Although its physical properties are inferior to those of ordinary silicate glasses, they are superior to those of some of the available materials used in infrared optics.
\end{abstract}

\section{Introduction}

Arsenic sulfide $\left(\mathrm{As}_{2} \mathrm{~S}_{3}\right)$ glass, although reported in 1870 [1], ${ }^{4}$ has received consideration only in recent years for its desirable spectral transparency to infrared radiation. It has a usable transmittance of radiant energy out to 12.0 or $12.5 \mu$, depending on thickness $[2,3]$.

The present investigation was undertaken to determine the chemical and physical properties of this glass and also to obtain pertinent information as to its suitability for use as an element of an optical system when exposed to the atmosphere.

Much of the material contained in this paper has been the subject of a report to the U. S. Air Force [4].

1 This work was supported first by the Department of the Navy, Bureau of Ships, and later by the United States Air Force, Wright Air Development Center, Materials Laboratory.

${ }^{2}$ Present address, Eastman Kodak Co., Rochester, N. Y.

${ }^{3}$ Deceased.

4 Figures in brackets indicate the literature references at the end of this paper.

\section{Preparation of the Glass}

The arsenic sulfide glass for most of the tests was made in the apparatus shown in figure $1 .{ }^{5}$ The arsenic and sulfur, in stoichiometric ratio of 2 to 3 plus a 0.25 percent excess of sulfur, were allowed to react in the reaction tube in an atmosphere of nitrogen, and then the arsenic sulfide was distilled at approximately $735^{\circ} \mathrm{C}$ into the accumulator. A typical time-temperature schedule for a $5,000-\mathrm{g}$ batch of arsenic sulfide is given in table 1. A slug: of glass, chilled by means of a stream of nitrogen impinging on the outlet tube, retained the distillate in the accumulator. Nitrogen was used throughout this operation to prevent oxidation. When the distillation was completed, the glass in the accumulator was stirred to homogenize it. Heat was then applied to the outlet tube, the stirrer was stopped, and the first slug of glass was caught in the tube suspended from the bottom of the molding oven. The mold was then quickly moved into place and

5 A patent has been applied for on this one-step procedure for making arsenic sulfide glass.

TABLE 1. Arsenic sulfide production run

(Operation sheet)

\begin{tabular}{|c|c|c|c|c|c|c|c|c|c|}
\hline \multirow{2}{*}{ Time } & \multicolumn{2}{|c|}{ Melt } & \multirow{2}{*}{ Condenser } & \multicolumn{2}{|c|}{ Accumulator } & \multirow{2}{*}{$\begin{array}{c}\text { Outlet } \\
\text { tube }\end{array}$} & \multicolumn{2}{|c|}{ Collecting oven- } & \multirow{2}{*}{ Remarks } \\
\hline & Top & Bottom & & Top & Bottom & & Top & Bottom & \\
\hline $\begin{array}{r}8: 00 \\
9: 00 \\
9: 30 \\
10: 00 \\
10: 30\end{array}$ & $\begin{array}{l}{ }^{\circ} \mathrm{C} \\
(\mathrm{a}) \\
495 \\
600 \\
715 \\
735\end{array}$ & $\begin{array}{l}{ }^{c} C \\
(\mathrm{a}) \\
450 \\
585 \\
695 \\
725\end{array}$ & $\begin{array}{l}{ }^{\circ} \mathrm{C} \\
(\mathrm{a}) \\
325 \\
345 \\
425 \\
440\end{array}$ & $\begin{array}{l}{ }^{\circ} \mathrm{C} \\
(\mathrm{a}) \\
330 \\
420 \\
490 \\
540\end{array}$ & $\begin{array}{l}{ }^{\circ} \mathrm{C} \\
(\mathrm{a}) \\
270 \\
355 \\
425 \\
480\end{array}$ & $\begin{array}{r}{ }^{\circ} C \\
(\mathrm{a}) \\
65 \\
100 \\
160 \\
245\end{array}$ & $\begin{array}{c}{ }^{\circ}{ }^{\mathrm{C}} \\
\text { (a) }\end{array}$ & $\begin{array}{c}{ }^{\circ} \mathrm{C} \\
\text { (a) }\end{array}$ & Current on. \\
\hline $\begin{array}{r}11: 00 \\
11: 30 \\
12: 00 \\
12: 30 \\
1: 00\end{array}$ & $\begin{array}{c}735 \\
760 \\
\end{array}$ & $\begin{array}{c}740 \\
725 \\
\end{array}$ & $\begin{array}{c}490 \\
420 \\
-\end{array}$ & $\begin{array}{l}570 \\
585 \\
565 \\
560 \\
560\end{array}$ & $\begin{array}{l}520 \\
555 \\
540 \\
540 \\
540\end{array}$ & $\begin{array}{l}300 \\
320 \\
325 \\
325 \\
320\end{array}$ & $\begin{array}{l}225 \\
255 \\
255 \\
260 \\
265\end{array}$ & $\begin{array}{l}220 \\
250 \\
250 \\
255 \\
260\end{array}$ & $\begin{array}{l}\text { Stirrer on (approximately } 240 \mathrm{rpm}) \text {. } \\
\text { Distillation completed. } \\
\text { Cut stirring speed to approximately } 180 \mathrm{rpm} \text {. }\end{array}$ \\
\hline $\begin{array}{l}1: 30 \\
2: 00 \\
2: 30 \\
3: 00 \\
3: 30\end{array}$ & $\begin{array}{ll}-1 \\
\cdots \cdots\end{array}$ & 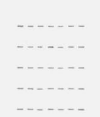 & 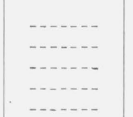 & $\begin{array}{l}545 \\
525 \\
515 \\
515 \\
515\end{array}$ & $\begin{array}{l}525 \\
505 \\
490 \\
490 \\
490\end{array}$ & $\begin{array}{l}325 \\
325 \\
320 \\
320 \\
325\end{array}$ & $\begin{array}{l}265 \\
265 \\
260 \\
260 \\
260\end{array}$ & $\begin{array}{l}260 \\
255 \\
255 \\
250 \\
250\end{array}$ & Cut stirring speed to approximately $120 \mathrm{rpm}$. \\
\hline 4:00 & ........ & ......... & ........ & 475 & 450 & 320 & 260 & 250 & Cast. \\
\hline
\end{tabular}

a Room temperature. 
the slab cast. After flow practically ceased (about $3 \mathrm{~min}$ ), a glass plate was placed over the mold and the mold and contents moved to an annealing oven at $185^{\circ} \mathrm{C}$. It was held at this temperature for 12 to $16 \mathrm{hr}$ and then slowly cooled to room temperature. For pieces weighing 2.0 to $2.5 \mathrm{~kg}$, the whole annealing operation took $3 \frac{1}{2}$ to $3 \frac{2}{3}$ days. No attempt was made to control the atmosphere in the annealing oven.

Although the apparatus shown in figure 1 permitted the use of either technical-grade or distilled arsenic without appreciably altering the quality of the glass, the large amount of residue left behind by the technical grade attacked the reaction tube, thereby shortening its life.

Some of the experiments were made on samples of glass obtained from a commercial source ${ }^{6}$ and others on experimental melts prepared at the Bureau by the one-step process described above.

The large thermal expansivity of the $\mathrm{As}_{2} \mathrm{~S}_{3}$ glass presented a distinct hazard to molding blanks successfully. The blanks, while being formed in Pyrex 7740 or Vycor, often stuck to the walls and bottom of the molds. Upon cooling, the differential expansion between the mold and specimen and the adhesion of the arsenic sulfide glass to the walls of the mold frequently resulted in severe fracture of both mold and specimen. This difficulty was overcome by lining the mold with aluminum foil, which eliminated sticking and allowed complete freedom of adjustment to the large dimensional changes that occur during cooling.

\footnotetext{
6 The commercial samples were produced by the American Optical Co., South-
bridge, Mass.
}

The transmittances of arsenic sulfide glasses made at the Bureau by similar procedures and of materials of comparable purity will agree within \pm 2 percent between 2 and $8 \mu$, except possibly in the region of the water absorption band at about $2.8 \mu$.

Nothing is known about the details of preparation of the commercial specimens. The commercial and experimental glasses are appreciably different in appearance and spectral transmittance in the visible and very near infrared as shown by data obtained with a Beckman quartz spectrometer, model DU (fig. 2).

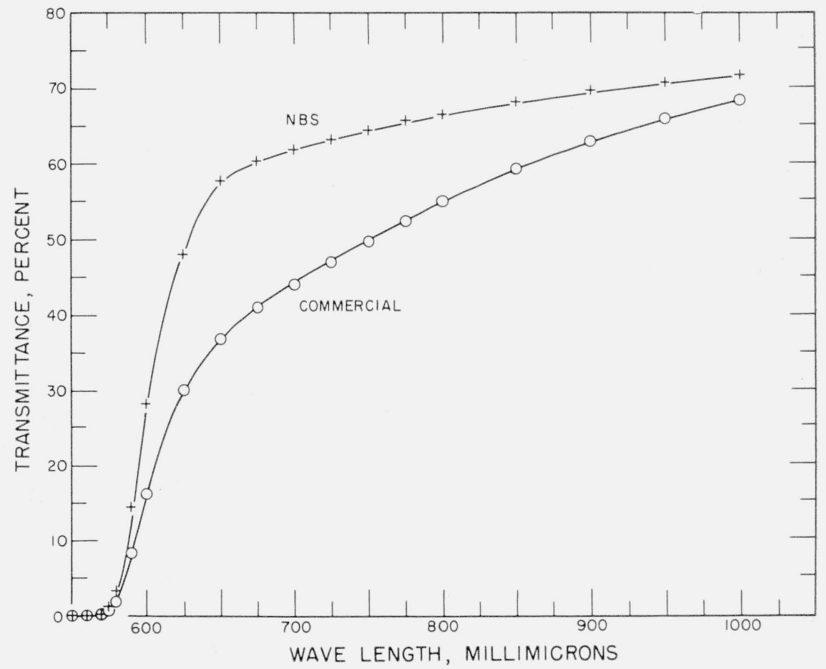

Figure 2. Comparison of the spectral transmittance of two samples of arsenic sulfide glass from $5 \mathrm{CO}$ to $1,000 \mathrm{m \mu}$. Specimens $6 \mathrm{~mm}$ thick.

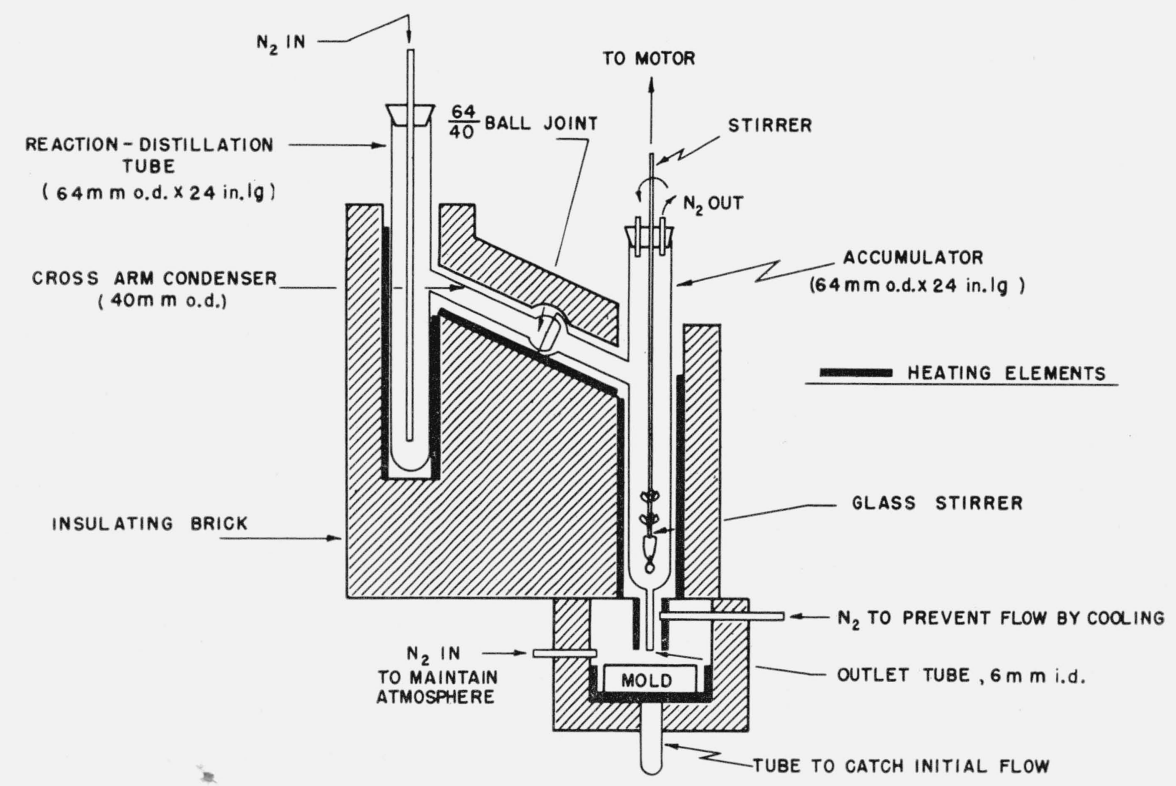

Figure 1. Schematic drawing of the apparatus used in the production of arsenic sulfide glass. 


\section{Chemical Properties}

\subsection{Hygroscopicity}

The hygroscopicity and chemical-durability data were obtained by the powder and interferometer procedures described in earlier publications $[5,6]$. In crushing and screening the powdered samples (approximately $1.5 \mathrm{~g}$ that passed a No. 150 Tyler standard sieve) for hygroscopicity determinations, the "fines" adhered conspicuously to the mortar, sieve, pan, walls of the hood, and the skin and clothing of the operator. Because the material is toxic, suitable precautions should be taken during this operation.
Figure 3, plotted from data given in table 2, shows the hygroscopicity curves (water sorbed versus hours of exposure to $98 \%$ relative humidity) for specimens of arsenic sulfide glass from two different sources, compared with those for fused $\mathrm{SiO}_{2}$, Vycor, Pyrex 7740, a window glass, and Corning 015. These silicate glasses furnish a reference index covering a broad cross section of commercial usage. Although the results obtained on the two samples differ from each other, both are considerably less hygroscopic than Pyrex 7740. One of the samples even compares favorably with fused $\mathrm{SiO}_{2}$ and Vycor, although this should not be interpreted as an indication of good chemical durability, as shown in figure 4

TABLE 2. Hygroscopicity, voltage characteristics, and chemical durabitity of arsenic sulfide glasses compared with similar properties of typical commercial glasses.

\begin{tabular}{|c|c|c|c|c|c|c|c|c|c|c|c|c|c|c|}
\hline \multirow{2}{*}{ Glasses } & \multicolumn{2}{|c|}{ Water sorbed } & \multicolumn{6}{|c|}{ Voltage departure at $p \mathrm{H}-$} & \multicolumn{6}{|c|}{ Surface alteration, $6 \mathrm{hr}, 80^{\circ} \mathrm{C}$, at $p \mathrm{H}-$} \\
\hline & $1 \mathrm{hr}$ & $2 \mathrm{hr}$ & 2 & 4. 1 & 6.0 & 8. 2 & 10. 2 & 11. 8 & 2 & 4.1 & 6.0 & 8.2 & 10.2 & 11.8 \\
\hline $\begin{array}{l}\text { Fused } \mathrm{SiO}_{2-} \\
\text { Vycor } \\
\mathrm{As}_{2} \mathrm{~S}_{3}(\mathrm{NBS})_{-}\end{array}$ & $\begin{array}{c}\mathrm{mg} / \mathrm{cm}^{3} \\
6.3 \\
8.1 \\
6 \\
---\end{array}$ & $\begin{array}{c}\mathrm{mg} / \mathrm{cm}^{3} \\
8 \\
10 \\
10 \\
- \\
\cdots\end{array}$ & $\begin{array}{r}m v \\
\text { (a) } \\
\text { (a) } \\
0 \\
0 \\
0\end{array}$ & $\begin{array}{l}m v \\
(\mathrm{~s}) \\
(\mathrm{a}) \\
105 \\
95 \\
120\end{array}$ & $\begin{array}{l}m v \\
(\mathrm{a}) \\
(\mathrm{a}) \\
202 \\
198 \\
191\end{array}$ & $\begin{array}{l}m v \\
\text { (a) } \\
(\mathrm{a}) \\
342 \\
303 \\
332\end{array}$ & $\begin{array}{l}m v \\
(\mathrm{a}) \\
(\mathrm{a}) \\
447 \\
438 \\
421\end{array}$ & $\begin{array}{l}m v \\
(\mathrm{a}) \\
(\mathrm{a}) \\
542 \\
552 \\
546\end{array}$ & $\begin{array}{c}\text { Fringes } \\
\text { bND } \\
\text { ND }\end{array}$ & $\begin{array}{c}\text { Fringes } \\
\text { ND } \\
\text { ND }\end{array}$ & $\begin{array}{c}\begin{array}{c}\text { Fringes } \\
\text { ND } \\
\text { ND }\end{array} \\
0\end{array}$ & $\begin{array}{c}\begin{array}{c}\text { Fringes } \\
\text { ND } \\
\text { ND }\end{array} \\
\end{array}$ & $\begin{array}{c}\begin{array}{c}\text { Fringes } \\
\text { oDA } \\
\text { AD }\end{array} \\
\end{array}$ & $\begin{array}{c}\text { Fringes } \\
1 / 2 \mathrm{~A} \\
1 / 2+\mathrm{A} \\
\cdots\end{array}$ \\
\hline $\begin{array}{l}\mathrm{As}_{2} \mathrm{~S}_{3}(\text { commercial) } \\
\text { Pyrex } 7740 \\
\text { Window } \\
\text { Corning } 015\end{array}$ & $\begin{array}{l}13 \\
16 \\
23 \\
61\end{array}$ & $\begin{array}{r}19 \\
28 \\
53 \\
125\end{array}$ & 0 & $7 \overline{7}$ & 165 & 288 & 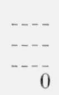 & 3 & $\begin{array}{l}\mathrm{d} 1 / 2 \mathrm{~S} \\
\mathrm{ND} \\
\mathrm{ND} \\
2 / 10-\mathrm{S}\end{array}$ & $\begin{array}{l}\frac{1 / 2-S}{N D} \\
\text { ND } \\
2 / 10-S\end{array}$ & $\begin{array}{l}1 / 4-\mathrm{S} \\
\mathrm{ND} \\
\mathrm{ND} \\
2 / 10-\mathrm{S}\end{array}$ & $\begin{array}{c}3 \mathrm{~A} \text { (variable) } \\
\text { DA } \\
\text { ND } \\
\text { eSC }\end{array}$ & $\begin{array}{l}114 \mathrm{~A} \\
1 / 4-\mathrm{A} \\
1 / 10+\mathrm{A} \\
1 / 4+\mathrm{A}\end{array}$ & $\begin{array}{c}1152 \mathrm{~A} \\
13 / 4 \mathrm{~A} \\
11 / 2-\mathrm{A} \\
2-\mathrm{A}\end{array}$ \\
\hline
\end{tabular}

a No definite $p H$ response. b ND, not detectable. o A, attack. d S, swelling. e SC, surface cut.

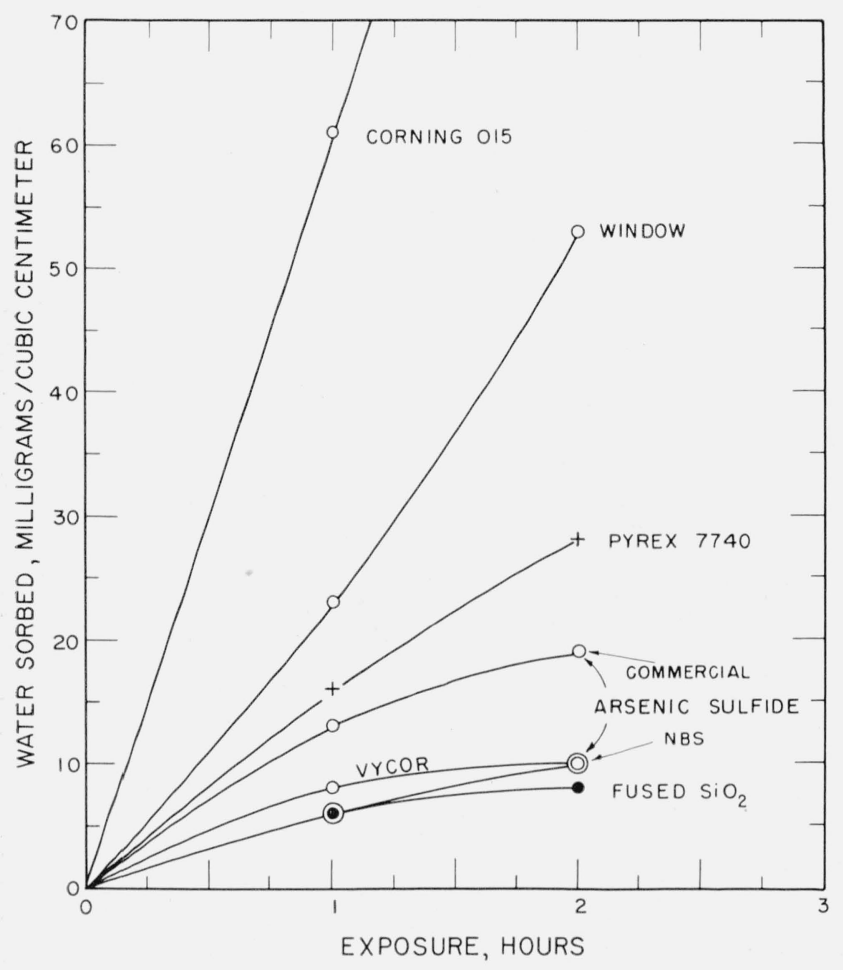

Figure 3. Comparison of the hygroscopicity of two samples of arsenic sulfide glass with similar data for fused silica, Vycor, Pyrex 7740, window, and Corning 015 glasses.

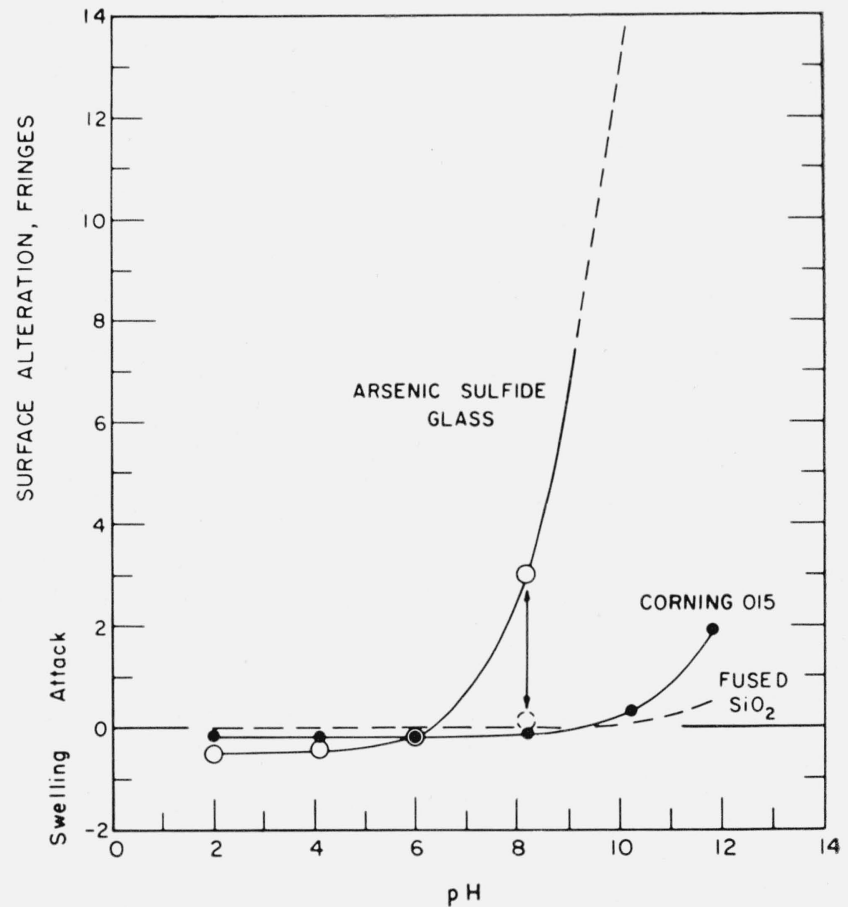

FIgure 4. Chemical durability of arsenic sulfide glass compared with similar data for Corning 015 glass and fused silica, over the range $p \mathrm{H} 2$ to $p \mathrm{H} 11.8$.

Exposure, $6 \mathrm{hr}$ at $80^{\circ} \mathrm{C}$. 
where fused silica and arsenic sulfide glasses are compared. The differences between these two $A_{2} \mathrm{~S}_{3}$ glasses, as shown by the hygroscopicity data, and which were also evident in the transmittance curves of figure 2, may be the result of impurities or variations in the arsenic-sulfur ratio.

\subsection{Chemical Durability}

\section{a. Swelling and Attack}

The chemical durability of the arsenic sulfide glass was reported as the surface alteration in interference fringes brought about by exposure of optically flat surfaces to various solutions under controlled conditions of temperature, time, and $p \mathrm{H}$. Test solutions chosen were the Britton-Robinson universal

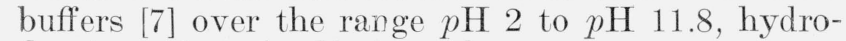
fluoric acid, and sulfuric acid.

There is general belief that the lower the hygroscopicity of a glass, the greater the ability of the glass surface to remain optically clear $[8,9]$. Judged on this basis from figure 3 and from the examination of polished samples which have been stored in the laboratory for approximately four years, both samples of $\mathrm{As}_{2} \mathrm{~S}_{3}$ would be expected to maintain optically clear surfaces over a considerable period.

Although the above indicates that arsenic sulfide glass has satisfactory serviceability, it rates very low in chemical durability as judged from figure 4 , plotted from data in table 2. In fact, it is inferior to the very hygroscopic, $p H$ responsive Corning 015 glass. Among the most interesting features of the curve for the chemical durability of $\mathrm{As}_{2} \mathrm{~S}_{3}$ glass, is the appreciable swelling in the acid range below $p \mathrm{H} 6$. Experimentally, the data between $p \mathrm{H} 2$ and $p \mathrm{H} 6$ were readily reproducible. At $p \mathrm{H} \mathrm{8,} \mathrm{however,}$ the attacks were variable, showing wide disagreement in results on duplicate samples ranging from difficultly detectable to large attack, as shown by the arrow in figure 4. Results in this region were highly dependent on just when the swollen layer sloughed off or dissolved. This is characteristic of glasses at $p \mathrm{H}$ values near which the surface alteration is passing through the transition from swelling to attack (approximately $p \mathrm{H}$ 7). The $\mathrm{As}_{2} \mathrm{~S}_{3}$ glass exhibited swelling of $1 / 2$ fringe (comparable with the swelling in acid buffer solutions) when exposed to distilled water for $6 \mathrm{hr}$ at $80^{\circ} \mathrm{C}$. At $p \mathrm{H} 11.8$, the attack was so rapid that the exposure time had to be reduced to $1 \mathrm{~min}$ at room temperature. The value plotted was calculated on the assumption that the rate of attack doubles for each $10 \mathrm{deg} \mathrm{C}$ rise in temperature [6]. This rapid attack in alkaline solutions is in line with the high solubility of $\mathrm{As}_{2} \mathrm{~S}_{3}$ in such solutions [10]. The swelling of the $\mathrm{As}_{2} \mathrm{~S}_{3}$ glass in the $p \mathrm{H}$ range of 2 to 6 is similar to that observed on the Corning 015 glass.

Table 3 gives the results obtained by progressively increasing the concentration of electrolyte in the ambient solution by the use of $\mathrm{H}_{2} \mathrm{SO}_{4}$. Figure 5

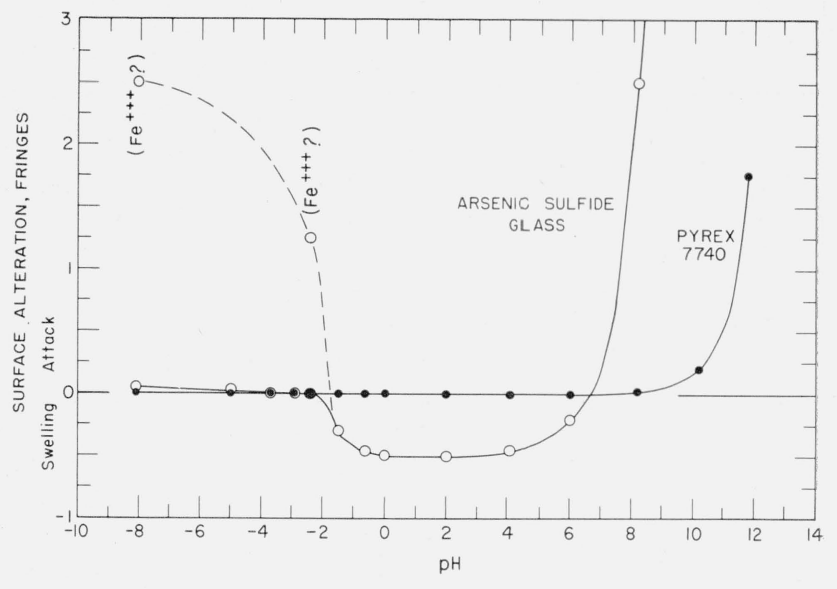

FIGURE 5. Chemical durability-pH curve for arsenic sulfide glass compared with a similar curve for Pyrex 7740 glass over the range $p \mathrm{H}-8.1$ (concentrated $\mathrm{H}_{2} \mathrm{SO}_{4}$ ) to $p \mathrm{H} 11.8$. Exposure, $6 \mathrm{hr}$ at $80^{\circ} \mathrm{C}$.

TABLE 3. Surface alterations of $\mathrm{As}_{2} \mathrm{~S}_{3}$ glass in aqueous $\mathrm{H}_{2} \mathrm{SO}_{4}$

\begin{tabular}{|c|c|c|}
\hline $\mathrm{H}_{2} \mathrm{SO}_{4}$ & $\mathrm{H}^{+}$ & $\begin{array}{l}\text { Surface alter- } \\
\text { ation, } 6 \mathrm{hr} \\
\text { at } 80^{\circ} \mathrm{C}\end{array}$ \\
\hline $\begin{array}{l}\text { Percent } \\
\mathrm{H}_{2} \mathrm{O} \\
10 \\
25 \\
50 \\
75\end{array}$ & $\begin{array}{c}p \mathrm{H} \\
-0.0 \\
0.62 \\
-1.49 \\
-2.45\end{array}$ & $\begin{array}{l}\quad \text { Fringes } \\
1 / 2 \mathrm{~S} \text { a } \\
1 / 2 \mathrm{~S} \\
1 / 2-\mathrm{S} \\
1 / 4+\mathrm{S} \\
\mathrm{N} \mathrm{D}^{\mathrm{b}},(11 / 4)^{\mathrm{c}}\end{array}$ \\
\hline $\begin{array}{l}80 \\
85 \\
90 \\
96 \\
96+\mathrm{FeCl}_{3}\end{array}$ & $\begin{array}{l}-2.9 \\
-3.7 \\
-5 \\
-8.1 \\
-\end{array}$ & $\begin{array}{l}\mathrm{ND} \\
\mathrm{ND} \\
\mathrm{DA}^{\mathrm{d}} \\
\mathrm{DA},(21 / 2)^{\mathrm{c}} \\
21 / 2+\mathrm{A}\end{array}$ \\
\hline
\end{tabular}

shows the over-all curve for chemical durability obtained by splicing these results onto the data furnished by the Britton universal buffer mixtures. Below $p \mathrm{H}-1$, the swelling is greatly repressed, with little or no surface alteration detectable in the majority of tests between $p \mathrm{H}-2.45$ and $p \mathrm{H}-8.2 .^{7}$ However, 2 specimens (plotted as dashed lines in fig. 5) out of more than 15 , showed vigorous attack in this "super acid" region. As similar attacks were obtained upon the addition of small amounts of ferric salts as an oxidizing agent, ${ }^{8}$ it was concluded that residual amounts of the ferric compounds present from the polishing rouge were probably respon-

Although such observed values as $p \mathrm{H} 8.2$ eannot be rationalized in the Arrnenius sense, i. e. they cannot possibly represent hydrogen-ion concentration in moles per liter [11], nevertheless these activities as indicated by the hydrogen electrode : saturated $\mathrm{KCl}$ cell are accepted and plotted for convenience.

8 Additional tests using $\mathrm{HCl}$ and $\mathrm{FeCl}_{3}$ mixtures gave attacks of $41 / 2$ interference fringes. 
sible for these exceptionally irregular results, i.e.,

$$
\mathrm{S}^{--}+2 \mathrm{Fe}^{+++}=\mathrm{S}+2 \mathrm{Fe}^{++} \text {. }
$$

The chemical-durability curve for Pyrex 7740 is included in figure 5 as a reference standard.

\section{b. Arsenic Sulfide Glass in Hydrofluoric Acid}

Silicate glasses are generally attacked vigorously by hydrofluoric acid with the formation of soluble products and volatile $\mathrm{SiF}_{4}$. The chemical durability of arsenic sulfide glass in $\mathrm{HF}$ solutions is of interest because the glass contains no silica. Preliminary experiments showed no displacement of fringes or other detectable alteration of polished flats upon exposure to 48-percent $\mathrm{HF}$ for $6 \mathrm{hr}$ at room temperature. At elevated temperatures, a perceptible swelling was observed after $1 \mathrm{hr}$ of exposure. Figure 6 shows the results obtained upon exposing specimens to 48 -percent $\mathrm{HF}$ at $80^{\circ} \mathrm{C}$ for various periods of time up to $6 \mathrm{hr}$. Swelling increased with time of exposure up to and including $4 \mathrm{hr}$, after which the swollen layer either became mechanically weak and sloughed off, or oxidized, forming soluble products. This attack, after $6 \mathrm{hr}$, was repeated on five different specimens, with similar results in each case.

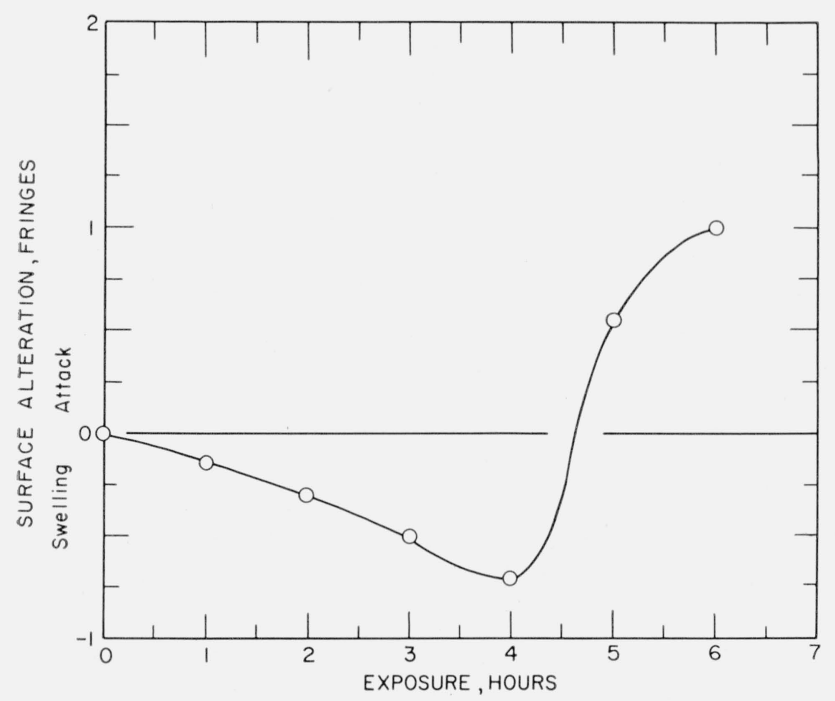

Figure 6. Chemical durability of arsenic sulfide glass in HF. Exposure, $6 \mathrm{hr}$, to 48 percent $\mathrm{HF}$ at $80 \mathrm{C}$.

\section{3. $p \mathrm{H}$ Response of Arsenic Sulfide Glass Electrodes}

For studying the $p \mathrm{H}$ response, electrodes were prepared by coating an aluminum rod (approximately $2-\mathrm{mm}$ diameter) with a film of the $\mathrm{As}_{2} \mathrm{~S}_{3}$ glass. This was accomplished by dipping the rod into the molten glass, and withdrawing and cooling sufficiently quickly to prevent ignition of the arsenic sulfide in the air. Aluminum was used because it has ap- proximately the same coefficient of expansion as the arsenic sulfide glass $\left(23.8 \times 10^{-6}\right.$ and $23.7 \times 10^{-6} /{ }^{\circ} \mathrm{C}$, respectively), and was the only material readily available for making successful electrodes of the Thompson metal-filled type [12]. This procedure was necessary because the conventional Cremer bulb type of electrode could not be blown [13].

All emf measurements were made at room temperature with a Beckman $p \mathrm{H}$ meter model $\mathrm{G}$, using a calibrated glass electrode as the reference half cell.

At the time of preparation, these arsenic sulfide electrodes had resistance values greatly exceeding $1,000 \mathrm{meg}$, and were incapable of initiating or sustaining readable voltages on the electrometer, i. e., they behaved as an open circuit. The resistance upon exposure to aqueous solutions fell quickly to a few megohms, and the electrodes then behaved essentially as punctured electrodes. Their initial performance was in accord with the very low hygroscopicity of the arsenic sulfide glass, whereas the later electrical response was compatible with the excessive swelling exhibited by this glass in acid solutions between $p \mathrm{H}-2$ and $p H-6$, and general overall poor chemical durability in the alkaline $p H$ range.

Figure 7 and table 2 give the voltage departures (errors) obtained on three arsenic sulfide glass electrodes immediately after preparation, compared with the corresponding departures of a $p \mathrm{H}$ responsive glass (Corning 015) and the calomel half cell. The latter has no electrical response to hydrogen ions. From this comparison, it is obvious that the arsenic sulfide glass electrodes exhibited little or no response to hydrogen ion activity of aqueous solutions. This lack of $p H$ response is in full accord with the low hygroscopicity and poor chemical durability of arsenic sulfide glass [10].

In order to establish that the data in figure 7 represent the performance of the arsenic sulfide, and not merely the characteristics of the aluminum electrical connector, the voltage characteristics of the bare aluminum rod were followed over the range $p \mathrm{H} 2$ and $p \mathrm{H}$ 11.8. Figure 8 and tables 4 and 5 show a comparison of the electrode performance with the reported chemical durability of $\mathrm{Al}$ metal [11] and the $p \mathrm{H}$ range of precipitation of $\mathrm{Al}(\mathrm{OH})_{3}$ [14]. The interesting feature of the voltage departure curve is the direction of drifts of the voltage below $p \mathrm{H} 4$ and above $p \mathrm{H}$ 11. These drifts are toward increasing departure, indicating the electrode is being attacked as shown by the durability curve. Between $p \mathrm{H} 4$ and $p \mathrm{H} \mathrm{11,} \mathrm{the} \mathrm{aluminum} \mathrm{electrode}$ tended to indicate the $\mathrm{H}$-ion concentration, with a steady reading appearing near $p H$ 8. The latter point should be near the $p \mathrm{H}$ of minimum solubility of Al metal in the buffers used. Inspection of these data suffices to establish that the voltage departure recorded for the glass electrodes in figure 7 is characteristic of arsenic sulfide glass and not of aluminum. 


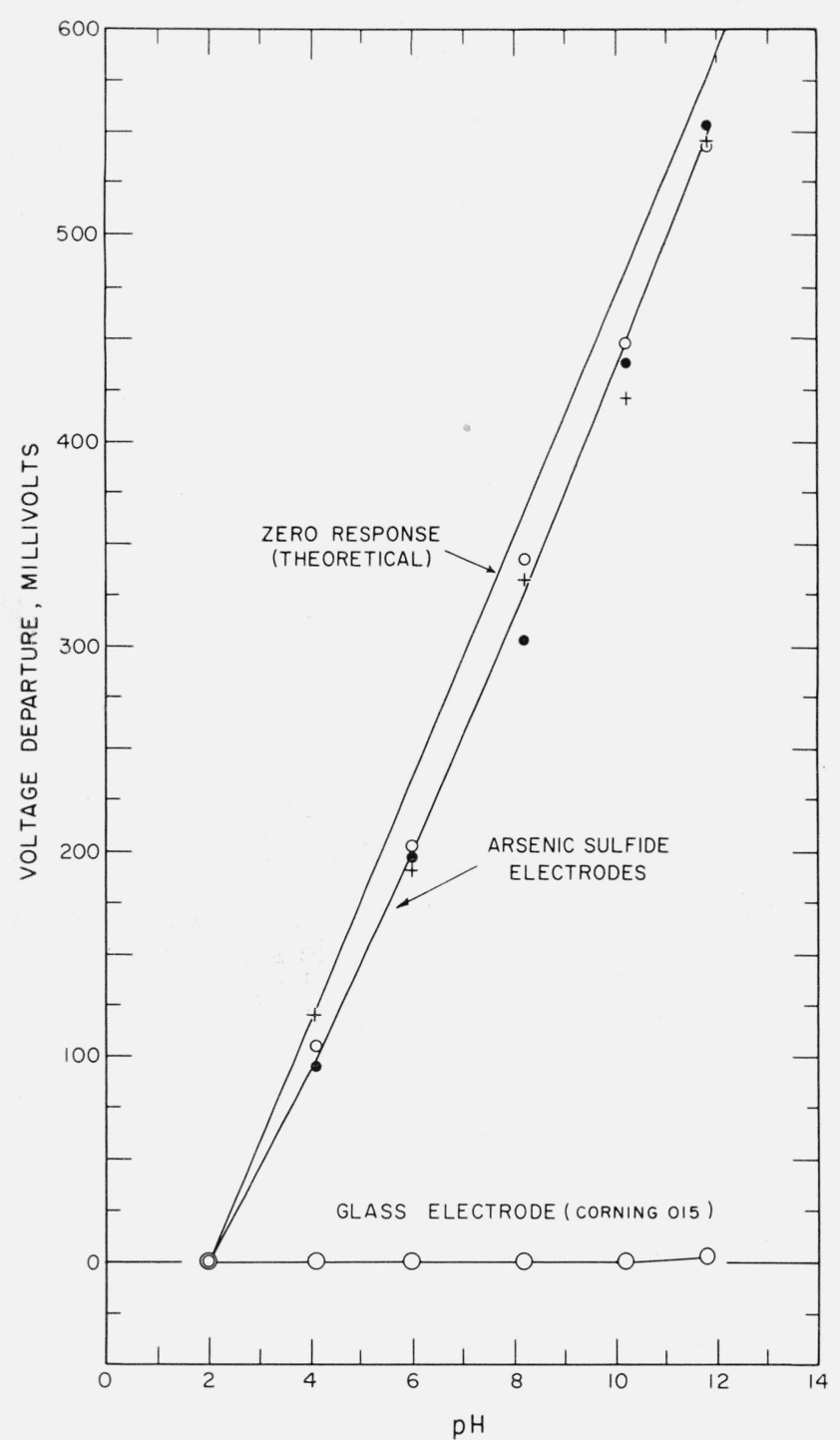

FiguRE 7. Voltage departures (errors) of electrodes prepared from arsenic sulfide glass.

(For comparison purposes, a curve is shown for an electrode having no hydrogen electrode function and for a glass electrode of Corning 015 glass, possessing approximately full $p H$ response).

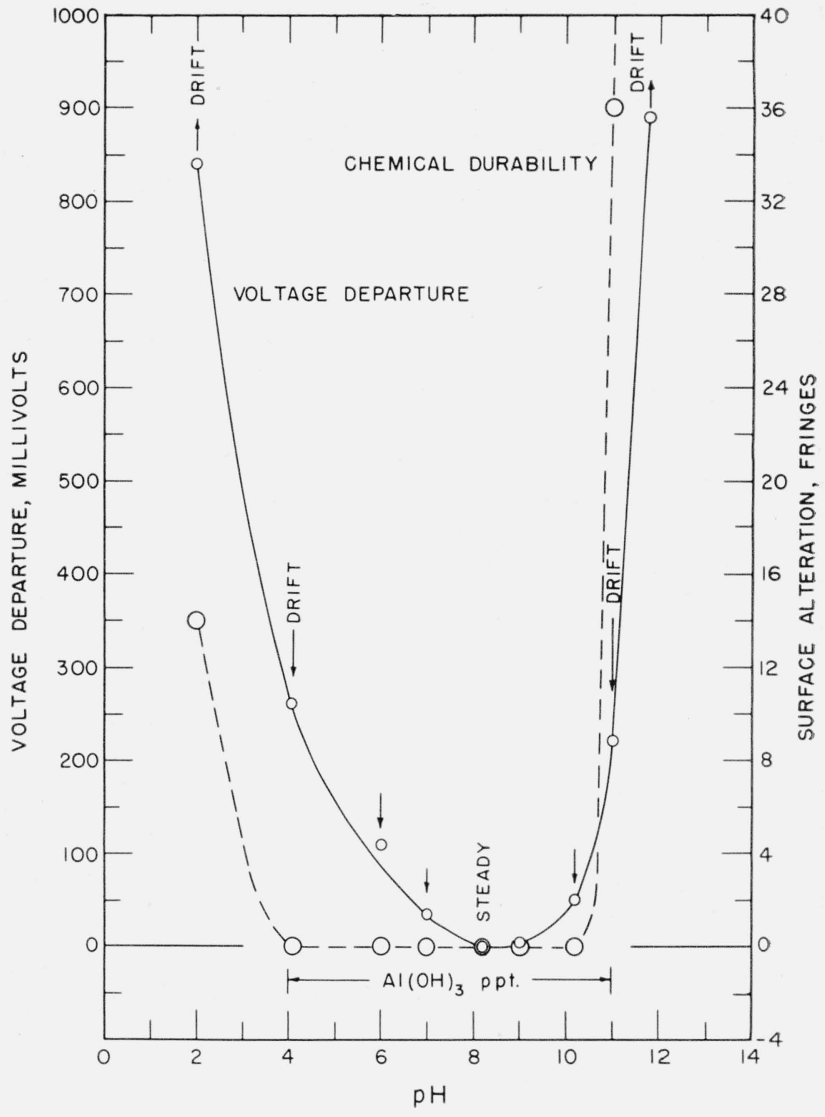

FIGURE 8. Voltage departure of an aluminum electrode over the range $p \mathrm{H} 2$ to $p \mathrm{H} 11.8$.

(For comparison purposes a curve is shown for the chemical durability of metallic aluminum, and also the $p \mathrm{H}$ range over which $\mathrm{Al}(\mathrm{OH})_{3}$ is precipitated is ind $\mathrm{i}$ cated). It is of interest to note the significance of this voltage drift curve in connection with the quantitative precipitation and successful filtration of $\mathrm{Al}(\mathrm{OH})_{3}$ from $\mathrm{Al}\left(\mathrm{NO}_{3}\right)_{3}$ by ammonia. [Clement Duval, Inorganic Thermogravimetric Analysis, p. 107, Elsevier Publishing Company, New York (1953)]. Precipitation is complete at $p \mathrm{H}$ 7.8. Immediate filtration at room temperature is possible. Imbibed water is driven off at $130^{\circ} \mathrm{C}$ and ignition to constant weight can be made at $475^{\circ} \mathrm{C}$. Thus this procedure has two interesting features; ease of filtration and drying at low temperature.

TABLE 4. Voltage characteristics of aluminum electrode, using the glass electrode as reference half cell

\begin{tabular}{|c|c|c|c|c|c|c|c|c|}
\hline \multicolumn{9}{|c|}{ Voltage departure at $p \mathrm{H}-$} \\
\hline 2.0 & 4.1 & 6.0 & 7.0 & 8.2 & 9.0 & 10.2 & 11 & 11.8 \\
\hline $\begin{array}{c}m v \\
810 \\
\text { Drift } \\
\text { Increase }\end{array}$ & $\begin{array}{c}m v \\
261 \\
\text { Drift } \\
\text { Increase }\end{array}$ & $\begin{array}{c}m v \\
109 \\
\text { Drift } \\
\text { Decrease }\end{array}$ & $\begin{array}{c}m v \\
34 \\
\text { Drift } \\
\text { Decrease }\end{array}$ & $\begin{array}{c}m v \\
0 \\
\text { Steady } \\
\end{array}$ & $\begin{array}{c}m v \\
6 \\
\text { Drift } \\
\text { Decrease }\end{array}$ & $\begin{array}{c}m v \\
51 \\
\text { Drift } \\
\text { Decrease }\end{array}$ & $\begin{array}{c}m v \\
221 \\
\text { Drift } \\
\text { Decrease }\end{array}$ & $\begin{array}{c}m v \\
880 \\
\text { Drift } \\
\text { Increase }\end{array}$ \\
\hline
\end{tabular}

TABLE 5. Chemical durabitity of aluminum metal exposed to Britton buffers for 6 hr at $80^{\circ} \mathrm{C}$

\begin{tabular}{|c|c|c|c|c|c|c|c|c|}
\hline \multicolumn{9}{|c|}{ Surface alteration at $p \mathrm{H}-$} \\
\hline 2.0 & 4.1 & 6.0 & 7.0 & 8.2 & 9.0 & 10.2 & 11 & 11.8 \\
\hline $\begin{array}{c}\text { Fringes } \\
13 \mathrm{~A} \mathrm{a}\end{array}$ & $\begin{array}{c}\text { Fringes } \\
\text { ND b }\end{array}$ & $\begin{array}{c}\text { Fringes } \\
\text { ND }\end{array}$ & $\begin{array}{c}\text { Fringes } \\
\text { ND }\end{array}$ & $\begin{array}{c}\text { Fringes } \\
\text { ND }\end{array}$ & $\begin{array}{c}\text { Fringes } \\
\text { ND }\end{array}$ & $\begin{array}{l}\text { Fringes } \\
\text { NDsc }\end{array}$ & $\begin{array}{c}\text { Fringes } \\
36 \mathrm{~A}\end{array}$ & $\begin{array}{c}\text { Fringes } \\
390 \mathrm{~A}\end{array}$ \\
\hline
\end{tabular}

a A, attack. b ND, not detectable. ${ }^{\mathrm{e}}$ se, surface cut. 


\section{Physical Properties}

\subsection{Thermal Expansion}

Expansion data were obtained by means of the Saunders modification of the interferometer procedure for measuring dilation [15]. Figure 9 shows a typical curve for the thermal expansion from room temperature to the deformation point of arsenic sulfide glass. The coefficient of expansion of this glass, $23.7 \times 10^{-6} /{ }^{\circ} \mathrm{C}$ between $50^{\circ}$ and $175^{\circ} \mathrm{C}$, is over 7 times that for Pyrex $7740\left(3.3 \times 10^{-6} /{ }^{\circ} \mathrm{C}\right)$, and approximately $2 \frac{1}{2}$ times that for common window and container glass.

\subsection{Elastic Moduli}

The elastic moduli were determined by the procedure used by Spinner [16]. Table 6 gives typical values for Young's and shear moduli and Poisson's ratio for annealed arsenic sulfide glass from $20^{\circ}$ to $190^{\circ}$ C. Both Young's and shear moduli decreased with increasing temperature, while Poisson's ratio increased. A graph of Young's and shear moduli versus temperature is given in figure 10 .

Arsenic sulfide glass has a Young's modulus of 162 kilobars at room temperature $\left(20^{\circ} \mathrm{C}\right)$, or approximately one-fourth that of ordinary glasses. This is very fortunate in respect to the thermal-shock resistance of this glass. The coefficient of thermal

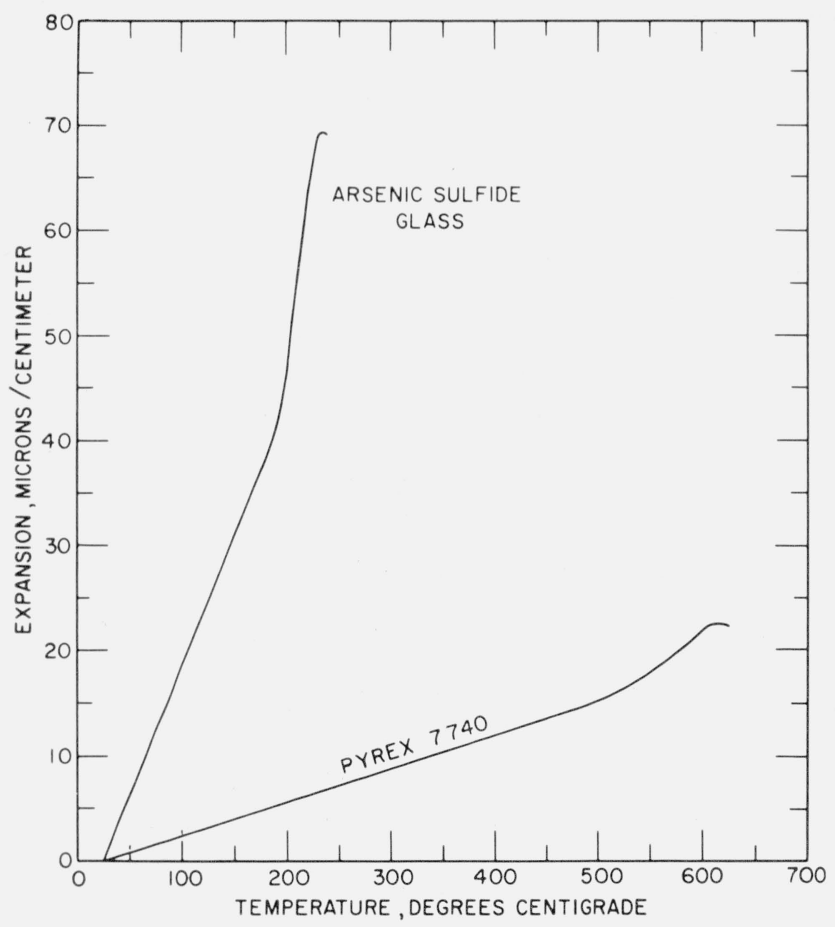

Figure 9. Comparison of the thermal expansion curve for $A s_{2} \mathrm{~S}_{3}$ with that of a thermal-shock-resistant glass (Pyrex $7 \% 40)$.

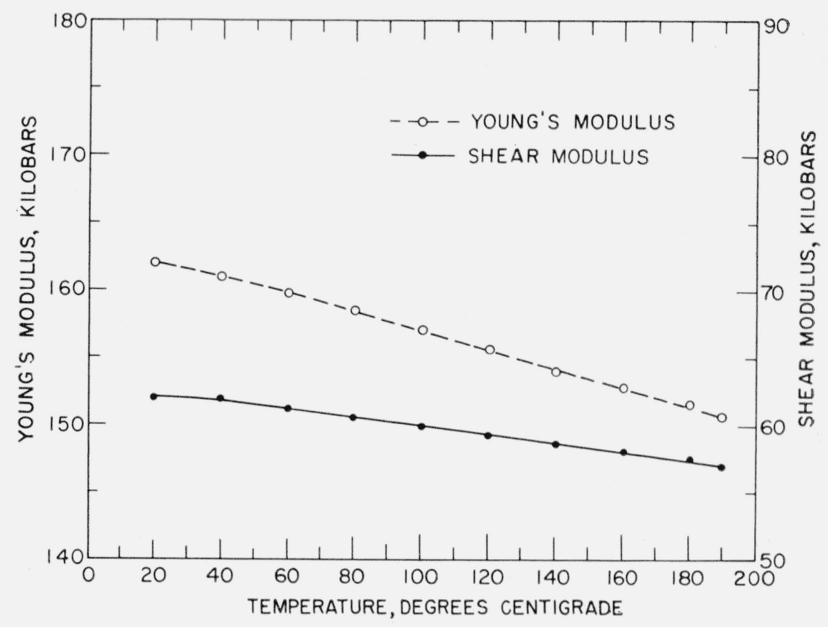

FIGURE 10. Young's and shear moduli versus temperature for NBS arsenic sulfide glass.

. - , Young's modulus; - - , shear modulus.

endurance, $F$, is defined by the expression,

$$
F=\frac{P}{\alpha E} \sqrt{\frac{K}{s c}}
$$

where $P$ is the tensile strength, $\alpha$ the coefficient of expansion, $E$ Young's modulus, $K$ thermal conductivity, $s$ the density, and $c$ the specific heat [17]. The low Young's modulus helps to counteract, to a certain extent, the high coefficient of thermal expansion, because the coefficient of thermal endurance varies inversely with their product. In spite of the low Young's modulus, the thermal-shock resistance is low in comparison with the regular glasses of commerce.

Table 6. Young's modulus, shear modulus, and Poisson's ratio versus temperature for arsenic sulfide glass

Annealed sample of glass made at NBS [4].

\begin{tabular}{|c|c|c|c|}
\hline $\begin{array}{c}\text { Tempera- } \\
\text { ture }\end{array}$ & $\begin{array}{c}\text { Young's } \\
\text { modulus } \\
(E)\end{array}$ & $\begin{array}{c}\text { Shear } \\
\text { modulus } \\
(G)\end{array}$ & $\begin{array}{c}\text { Poisson's } \\
\text { ratio }\end{array}$ \\
\cline { 1 - 1 } & & & \\
\hline & & & \\
\hline${ }^{C}$ & Kilobars & Kilobars & \\
40 & 162.0 & 62.0 & 0.306 \\
69 & 160.8 & 61.9 & .299 \\
80 & 159.5 & 61.1 & .305 \\
100 & 158.1 & 60.5 & .307 \\
129 & 156.7 & 59.8 & .310 \\
140 & 155.2 & 59.2 & .311 \\
160 & 153.4 & 58.7 & .307 \\
180 & 152.3 & 58.1 & .311 \\
190 & 150.9 & 57.4 & .314 \\
& 149.9 & 57.0 & .315 \\
& & & \\
\hline
\end{tabular}

Although flat specimens of the $A s_{2} \mathrm{~S}_{3}$ glass could only withstand quenching thermal shocks of less than $20^{\circ} \mathrm{C}$, the same specimens could be placed on an aluminum plate at $300^{\circ} \mathrm{C}$ without breaking. Observations with the polariscope revealed that in the latter situation, both the upper and lower sur- 
faces of the specimens were placed in compression The large expansion of the hot lower surface caused the specimen to curl upward, placing the upper surface in compression. At the same time, as long as the main bulk of the slab remains below the deformation temperature, the lower surface was also held in compression. As soon as the deformation temperature is reached, the stresses are released and still no breakage can occur.

\subsection{Modulus of Rupture}

The modulus of rupture was determined on a transverse strength apparatus with midpoint loading. Values for annealed and "toughened" arsenic sulfide glass specimens made at the National Bureau of Standards are given in table 7 . These measure-

TABLE 7. Modulus of rupture of arsenic sulfide glass specimens made at the National Bureau of Standards (4-in. span) [4]

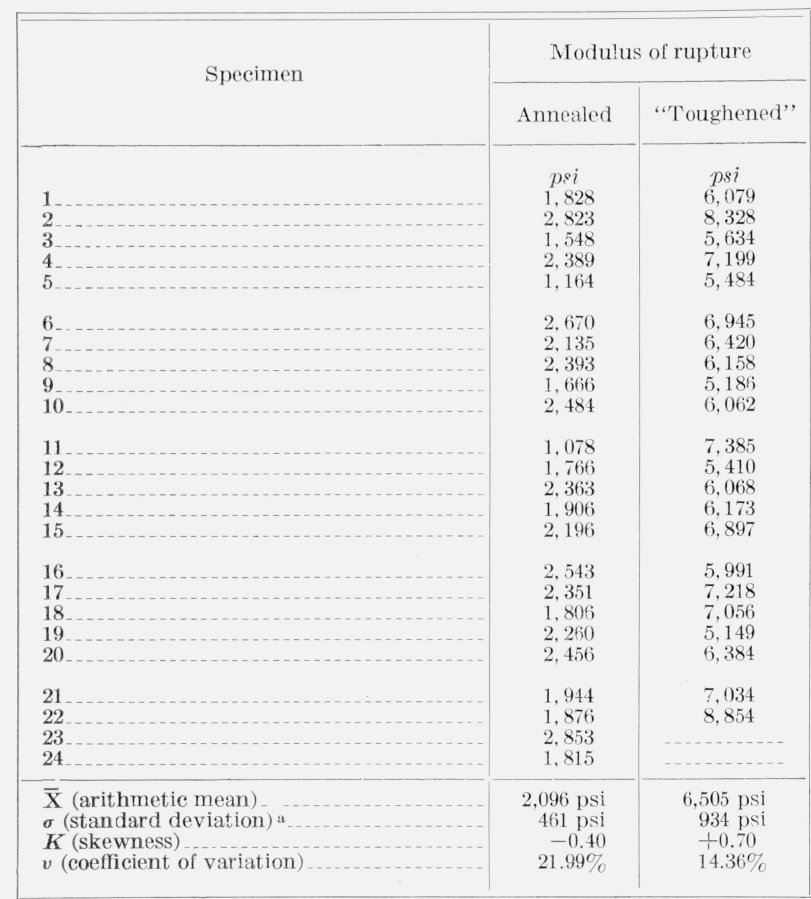

a This is the standard deviation of the individual values from the mean

ments were made on specimens approximately 0.4 by 0.7 by 6.0 in. long, using a 4 -in. span. The process used in "tempering" or "toughening" arsenic sulfide glass consisted of heating the specimens to $250^{\circ} \mathrm{C}$, quenching them in oil at $130^{\circ} \mathrm{C}$, and leaving the specimens to cool in the oil. As can be seen from the table, the "toughening" treatment increased the arithmetic mean of the modulus of rupture from 2,096 to 6,505 psi, or 3.1 times. Although the standard deviation was higher for the "toughened" samples (934 against 461 psi for the annealed samples), the coefficient of variation was less (14.36 to $21.99 \%$ ).

\subsection{Hardness}

The Knoop hardness of annealed arsenic sulfide glass was found to be 120 to 125 . However, when these same samples were "toughened" and again tested, the Knoop hardness was only 100 to 111. The Knoop hardness of commercially annealed soda-lime glass is 520; that for lead glasses varies from 370 to 440 , depending on the lead content [18].

\subsection{Optical Properties}

\section{a. Transmittance}

The infrared transmittance curve for two thicknesses of arsenic sulfide glass made at the National Bureau of Standards is shown in figure 11. These measurements were made by the Radiometry Section of the Bureau. Figure 12 shows the absorbance index and surface loss (one surface) calculated from the results plotted in figure 11 [19]. As can be seen, the maximum transmittance obtainable is about 70 percent because of the high reflection loss. This high loss is due to the high index of refraction, 2.4 in the infrared. Figure 13 gives an idea of the difference in transmittance between a sample made at the National Bureau of Standards and a commercial sample made by the American Optical Company. These same samples were then "toughened" and their transmittances again measured. A comparison of the transmittance curves before and after "toughening" indicated that the "toughening" process did not affect the transmittance in the infrared. Also, though there are differences between the transmittances of the two samples (NBS and commercial), the over-all transmittances of the two glasses are practically the same.

It will be noticed that there is appreciable difference between the transmittance curves in figures 11 and 13. The glass sample used for figure 11 resulted from a small melt (230 g of batch); the

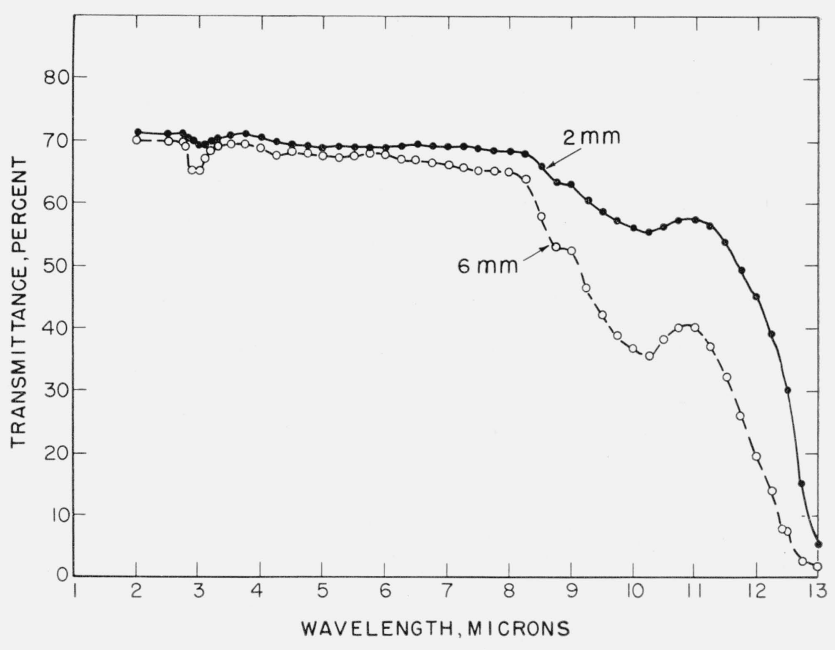

FIGURE 11. Infrared transmittances of two thicknesses of arsenic sulfide glass produced at NBS.

- $\mathrm{t}=2 \mathrm{~mm} ; \ldots . ., \mathrm{t}=6 \mathrm{~mm}$. 


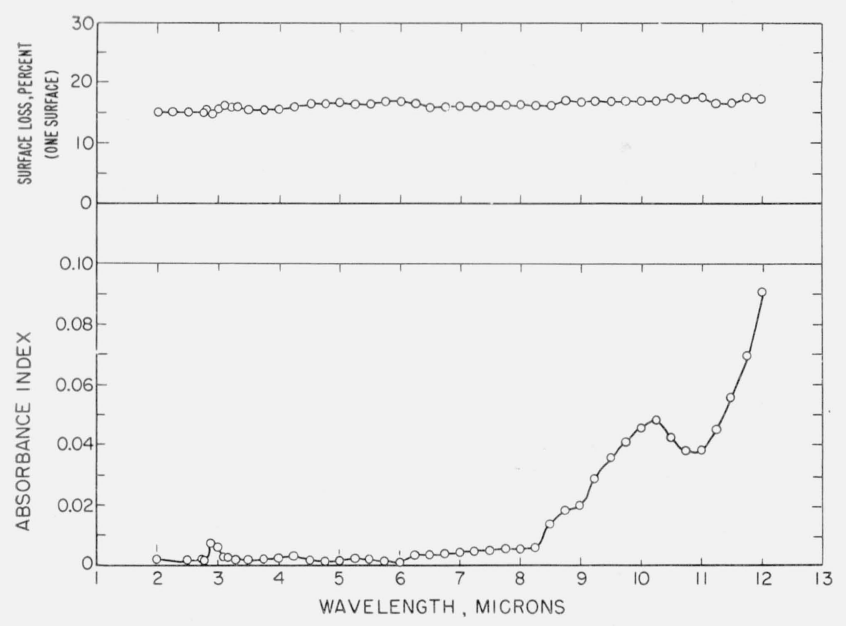

Figure 12. Surface loss (one surface) and absorbance indices calculated from figure 11 .

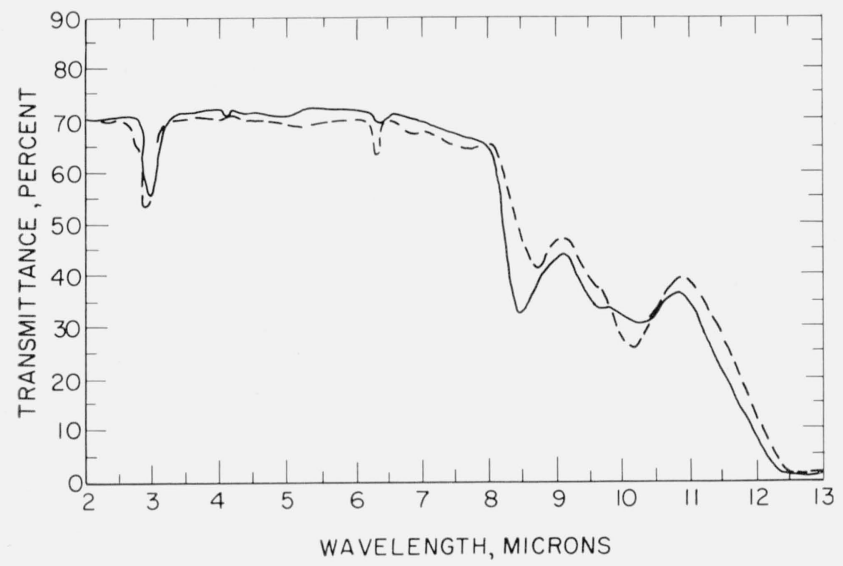

FIGURE 13. Infrared transmittance curves for commercial and NBS arsenic sulfide glass. Annealed.

, commercial glass, $\mathrm{t}=6.05 \mathrm{~mm}$; ......, NBS glass, $\mathrm{t}=6.00 \mathrm{~mm}$.

sample used for figure 13 resulted from a large melt $(5,000 \mathrm{~g}$ of batch) made in the one-step process described previously. Also, in the case of the small melt, doubly distilled arsenic was used; in the large melt, singly distilled arsenic was used. In the small melt, $1 \mathrm{ml}$ of water was added to the batch to displace any residual air; in the large melt, none was added. The small melt was not cast, but was annealed in the reaction tube after homogenizing. The differences in the procedures enumerated above can easily account for the differences in the two transmittance curves.

\section{b. Indices of Refraction}

To our knowledge, only one measurement of the indices of refraction of arsenic sulfide glass in the infrared has been made. That measurement was made at the National Bureau of Standards, by the Optical Instruments Section, on a prism furnished by Walter A. Fraser, at that time working in the Research Laboratories of the American Optical Co., Stanford, Conn. The dispersion curve for this prism is shown in figure 14, plotted from the results given in table 8.

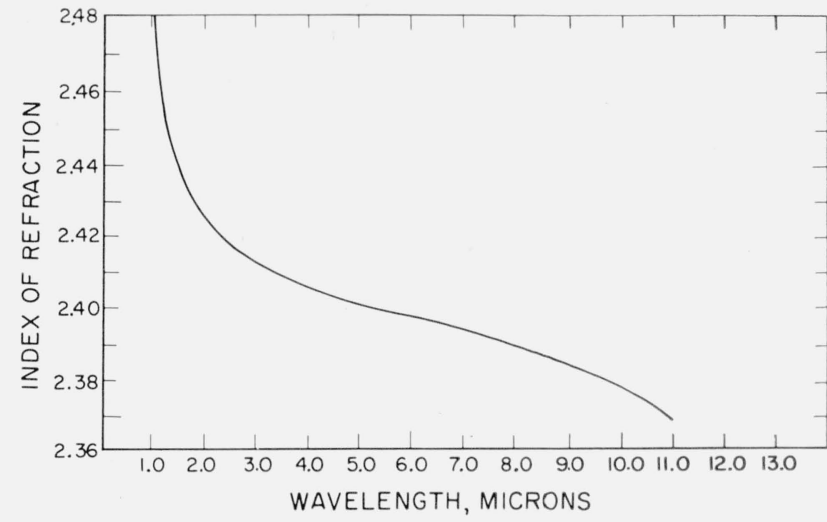

FiguRE 14. Dispersion curve for arsenic sulfide glass.

(This glass was produced by Walter A. Fraser while in the employ of the American Optical Co., Southbridge, Mass. Measurements were made at NBS.)

TABLE 8. Index of refraction of a prism of arsenic sulfide glass produced by Walter A. Fraser while at the American Optical Co., Southbridge, Mass.

Determinations made at NBS.

\begin{tabular}{|c|c|}
\hline $\begin{array}{l}\text { Wavelength } \\
\text { (microns) }\end{array}$ & $\begin{array}{l}\text { Index of } \\
\text { refraction }\end{array}$ \\
\hline $\begin{array}{l}0.579066 \\
.643847 \\
1.01398 \\
1.12866 \\
1.35703\end{array}$ & $\begin{array}{l}\text { 2. } 65822 \\
2.59413 \\
2.47230 \\
2.45897 \\
2.44244\end{array}$ \\
\hline $\begin{array}{l}\text { 1. } 36728 \\
\text { 1. } 39506 \\
1.52952 \\
1.6932 \\
1.7092\end{array}$ & $\begin{array}{l}2.44190 \\
2.44050 \\
2.43474 \\
2.42965 \\
2.42913\end{array}$ \\
\hline $\begin{array}{l}1.81307 \\
1.97009 \\
2.32542 \\
3.3033 \\
3.4188\end{array}$ & $\begin{array}{l}2.42656 \\
2.42341 \\
2.41848 \\
2.41134 \\
2.41068\end{array}$ \\
\hline $\begin{array}{r}5.344 \\
6.238 \\
8.662 \\
9.724 \\
11.035\end{array}$ & $\begin{array}{l}2.39900 \\
2.39718 \\
2.38734 \\
2.38029 \\
2.37055\end{array}$ \\
\hline
\end{tabular}

\section{Conclusions}

The very low hygroscopicity exhibited by arsenic sulfide glass is a characteristic favorable to its use as an optical element. It is better than any other material of which we know, within its useful transmission range out to approximately $13 \mu$, for the optical elements of laboratory infrared instruments, for that reason. Infrared spectrometer cells made from it would be satisfactory for neutral or slightly acid organic liquids and water solutions. However, because of its low Knoop hardness, precautions should be taken to protect it when used in optical systems or as windows. It is also very easily attacked by alkaline and oxidizing materials.

The very high coefficient of expansion and low modulus of rupture tend to limit the thermal shock that can be withstood. Hence, caution must be exercised in molding procedures, mounting design, and service usage. The low value of Young's modulus, however, does, to a certain extent, counteract the effect of the high coefficient of expansion. 


\section{References}

[1] C. Schultz-Sellack, Diathermansie einer Reihe von Stoffen für Wärme sehr geringer Brechbarkeit, Ann. Physik 139, 182 (1870).

[2] Rudolf Frerichs, New optical glasses with good transparency in the infrared, J. Opt. Soc. Amer. 43, 1153 (1953).

[3] W. A. Fraser and J. Jerger, Jr., Arsenic trisulfide: A new infrared transmitting glass, J. Opt. Soc. Amer. 43, 322 A (1953); W. A. Fraser, A new triaxial system of infrared glasses, J. Opt. Soc. Amer. 43, 823 A (1953); Servo Corporation of America, 20-20 Jericho Turnpike, New Hyde Park, N. Y., a leaflet entitled "Servofrax" (arsenic trisulfide glass); W. A. Fraser, Arsenic trisulfide glass and its applications, Proceedings of the conference on infrared optical materials, filters, and films, p. 25 (Held at the Engineer Research and Development Laboratories, Fort Belvoir, Va., 10 February 1955); and Francis W. Glaze, Transmittance of infrared energy by glasses, Bul. Am. Ceram. Soc. 34, 291 (1955).

[4] F. W. Glaze, D. H. Blackburn, and W. Capps, Development of materials for transmitting infrared ensgy, WADC technical report 54-457, project No. 7350, Materials Laboratory, Wright Air Development Center, United States Air Force, Wright-Patterson Air Force Base, Ohio (March 1955).

[5] Donald Hubbard, Mason H. Black, Sylvanus F. Holley, and Gerald F. Rynders, Electrode function $(p \overrightarrow{\mathrm{H}}$ response), hygroscopicity and chemical durability of soda-potash-silica glasses, J. Research NBS 46, 168 (1951) RP2189.

[6] Donald Hubbard and Edgar H. Hamilton, Studies of the chemical durability of glass by an interferometer method, J. Research NBS $\mathbf{2 y}, 143$ (1941) RP1409.
[7] H. T. S. Britton, Hydrogen ions (D. Van Nostrand Co., Inc., New York, N. Y., 1932).

[8] Donald Hubbard, Hygroscopicity of optical glasses as an indicator of serviceability, J. Research NBS 36, 365 (1946) RP1706.

[9] George W. Morey, The properties of glass, p. 107 (Reinhold Publishing Corp., New York, N. Y. 1954).

[10] Herman F. Shermer, Gerald F. Rynders, Given W. Cleek, and Donald Hubbard, Atypical $p \mathrm{H}$ response of some nonsilicate glasses, J. Research NBS 52, 251 (1954) RP2497.

[11] Robert G. Pike and Donald Hubbard, An interferometer procedure applied to the study of the chemical durability of silicates, enamels, and metals, J. Research NBS 50, 87 (1953) R P2394.

[12] M. R. Thompson, A metal-connected glass electrode, BS J. Research 9, 833 (1932) RP511.

[13] M. Cremer, On the causes of the electromotive properties of tissues and a discussion of polyphase electric cells, Z. Biol. 47, 562 (1906).

[14] Lansing S. Wells, Reaction of water on calcium aluminate, BS J. Research 1, table 15 (1928) RP34.

[15] James B. Saunders, Improved interferometric procedure with application to expansion measurements, J. Research NBS 23, 179 (1939) RP1227.

[16] Sam Spinner, Elastic moduli of glasses by a dynamic method, J. Am. Ceram. Soc. 37, 229 (1954).

[17] George W. Morey, The properties of glass, p. 351 (Reinhold Publishing Corp., New York, N. Y., 1954).

[18] Fay V. Tooley, Handbook of glass manufacture, p. 15. (Ogden Publishing Co., New York 36, N. Y., 1953).

[19] Jack M. Florence, Charles C. Allshouse, Francis W. Glaze, and Clarence $\mathrm{H}$. Hahner, Absorption of nearinfrared energy by certain glasses, J. Research NBS 45, 121 (1950) RP2118.

Washington, November 9, 1956. 